\title{
Monoclonal Antibody to Colorectal Cancer
}

National Cancer Institute

\section{Source}

National Cancer Institute. Monoclonal Antibody to Colorectal Cancer. NCI Thesaurus. Code C29721.

A monoclonal antibody (MOAB) directed against an antigen expressed by colorectal cancer cells. ( $\mathrm{NClO4})$ 